University of Nebraska - Lincoln

DigitalCommons@University of Nebraska - Lincoln

USDA National Wildlife Research Center - Staff Publications
U.S. Department of Agriculture: Animal and Plant Health Inspection Service

2011

\title{
Anthraquinone-based bird repellent for sunflower crops
}

\author{
Scott J. Werner \\ USDA/APHIS/ WS/ National Wildlife Research Center, scott.j.werner@aphis.usda.gov
}

George M. Linz

USDA/APHIS/WS National Wildlife Research Center, george_m_linz@yahoo.com

James C. Carlson

USDA/APHIS/WS National Wildlife Research Center, james.c.carlson@aphis.usda.gov

Susan E. Pettit

USDA-APHIS, Wildlife Services' National Wildlife Research Center

Shelagh K. Tupper

USDA-APHIS, Wildlife Services' National Wildlife Research Center, shelagh.t.deliberto@usda.gov

See next page for additional authors

Follow this and additional works at: https://digitalcommons.unl.edu/icwdm_usdanwrc

Werner, Scott J.; Linz, George M.; Carlson, James C.; Pettit, Susan E.; Tupper, Shelagh K.; and Santer, Michele M., "Anthraquinone-based bird repellent for sunflower crops" (2011). USDA National Wildlife Research Center - Staff Publications. 1379.

https://digitalcommons.unl.edu/icwdm_usdanwrc/1379

This Article is brought to you for free and open access by the U.S. Department of Agriculture: Animal and Plant Health Inspection Service at DigitalCommons@University of Nebraska - Lincoln. It has been accepted for inclusion in USDA National Wildlife Research Center - Staff Publications by an authorized administrator of DigitalCommons@University of Nebraska - Lincoln. 


\section{Authors}

Scott J. Werner, George M. Linz, James C. Carlson, Susan E. Pettit, Shelagh K. Tupper, and Michele M. Santer 


\title{
Anthraquinone-based bird repellent for sunflower crops
}

\author{
Scott J. Werner ${ }^{\mathrm{a}, *}$, George M. Linz ${ }^{\mathrm{b}}$, James C. Carlson ${ }^{\mathrm{a}}$, Susan E. Pettit ${ }^{\mathrm{a}}$, Shelagh K. Tupper ${ }^{\mathrm{a}}$, \\ Michele M. Santer ${ }^{\mathrm{c}}$ \\ a United States Department of Agriculture, Animal and Plant Health Inspection Service, Wildife Services, National Wildlife Research Center, 4101 LaPorte \\ Avenue, Fort Collins, CO 80521-2154, USA \\ b United States Department of Agriculture, Animal and Plant Health Inspection Service, Wildlife Services, National Wildlife Research Center, North Dakota \\ Field Station, 2110 Miriam Circle, Bismarck, ND 58501-2502, USA \\ c Arkion Life Sciences, 551 Mews Drive-Suite J, New Castle, DE 19720, USA
}

\section{A R T I C L E I N F O}

\section{Article history:}

Accepted 11 November 2010

Available online 17 December 2010

\section{Keywords:}

Chemical repellent

Confectionery sunflower

Helianthus annuus

Oilseed sunflower

Phasianus colchicus

Quiscalus quiscula

\begin{abstract}
A B S T R A C T
Non-lethal alternatives are needed to manage bird damage to confectionery and oilseed sunflower crops (Helianthus annuus). Ring-necked pheasants (Phasianus colchicus) can cause localized damage to newly planted sunflower, and blackbirds (Icterids) damage ripening sunflower annually in the United States of America. We conducted seed germination experiments, a repellent efficacy study with ring-necked pheasants and Avipel ${ }^{\circledR}$ repellent (a.i. 50\% 9,10-anthraquinone), and laboratory and field efficacy studies with common grackles (Quiscalus quiscula) and Avipel $^{\circledR}$-treated confectionery sunflower. Compared to the germination of seeds not treated with anthraquinone, we observed no negative effects of up to $12,223 \mathrm{ppm}, 14,104 \mathrm{ppm}$, and $11,569 \mathrm{ppm}$ anthraquinone seed treatments for germination of confectionery sunflower, oilseed sunflower, and canola seeds, respectively. Pheasants avoided emergent sunflower seedlings (12 days post-planting) from $15,800 \mathrm{ppm}$ anthraquinone seed treatments during a caged preference test $(P=0.045)$. We observed a positive concentration-response relationship $(P=0.001)$ and predicted a threshold concentration (i.e., $80 \%$ repellency) of $9200 \mathrm{ppm}$ anthraquinone for common grackles offered Avipel ${ }^{\circledR}$-treated confectionery sunflower seeds. Grackles also reliably discriminated between untreated sunflower and seeds treated with $1300 \mathrm{ppm}$ anthraquinone in captivity $(P<0.001)$. During our field efficacy study for ripening confectionery sunflower, we observed $18 \%$ damage among anthraquinone-treated enclosures and $64 \%$ damage among untreated enclosures populated with common grackles $(P<0.001)$. Harvested seed mass averaged $2.54 \mathrm{~kg}$ (dry weight) among treated enclosures and $1.24 \mathrm{~kg}$ among untreated enclosures $(P<0.001)$. Our laboratory and field efficacy data provide a reliable basis for planning future field applications of anthraquinone-based repellents for protection of sunflower crops. Supplemental field efficacy studies are necessary for development of an effective avian repellent and management of avian depredation of ripening agricultural crops, including oilseed sunflower.
\end{abstract}

Published by Elsevier B.V.

\footnotetext{
* Corresponding author. Tel.: +1 970266 6136; fax: +1970266 6138 .

E-mail address: Scott.J.Werner@aphis.usda.gov (S.J. Werner).
}

\section{Introduction}

The gregarious feeding behavior of red-winged blackbirds (Agelaius phoeniceus), common grackles (Quiscalus quiscula), and yellow-headed blackbirds (Xanthocephalus xanthocephalus) negatively impacts production of ripening sunflower each year in the United States of America 
(USA; Linz and Hanzel, 1997; Werner et al., 2005, 2009, 2010). Blackbird damage to sunflower was estimated to be $\$ 5.4$ million annually in the USA (Peer et al., 2003).

The South Dakota Department of Agriculture (Pierre, SD, USA) conducted a poll in February-March 2009 to determine the need for an avian repellent to protect newly planted sunflower seed from consumption by ring-necked pheasants (Phasianus colchicus). Approximately $14 \%$ ( $n=67$ ) of the estimated 478 South Dakota sunflower producers responded to the survey. Among the respondents, 98\% reported sunflower seed or seedling losses from ring-necked pheasants. Fortytwo percent of survey respondents reported <20 ha damaged by ring-necked pheasants. Sunflower damage attributable to ring-necked pheasants was reportedly $5-10 \%$ yield loss among 19\% of survey respondents, and $11-20 \%$ and $21-50 \%$ yield loss for an additional $19 \%$ and $21 \%$ of respondents, respectively. Pheasants can also cause localized damage to newly planted corn (West et al., 1969), and canola seeds and seedlings (B. Coleman, Northern Canola Growers Association, pers. comm.).

Chemical repellents are a socially acceptable, non-lethal approach to managing avian depredation of agricultural crops (Avery et al., 2005; Cummings et al., 2002a,b; Linz et al., 2006; Werner et al., 2007, 2008a,b, 2009, 2010). Anthraquinone was identified as a promising avian repellent in the early 1940s (Heckmanns and Meisenheimer, 1944). Anthraquinone is an emodin (i.e., phenolic) purgative; its action is principally on the large intestine, and it is not effective if transit through the small intestine is delayed (Merck, 1991). Anthraquinone-based repellents have been used to effectively protect rice seed from blackbirds under captive and field conditions (Avery et al., 1997, 1998; Cummings et al., 2002a,b; Neff and Meanley, 1957). Additionally, threshold concentrations for anthraquinone repellency were recently estimated for Canada geese, redwinged blackbirds, and ring-necked pheasants (Werner et al., 2009). Although anthraquinone is a naturally occurring substance, no anthraquinone-based repellents are currently registered for agricultural applications in the USA.

Our purpose was to obtain laboratory and field efficacy data necessary for development of an effective chemical repellent for protection of sunflower crops. Our objectives were to evaluate an anthraquinone-based repellent for protection of newly planted and ripening sunflower from ring-necked pheasant and common grackle damage, respectively. We therefore conducted seed germination experiments and a repellent efficacy study with ringnecked pheasants and anthraquinone seed treatments, and laboratory and field efficacy studies with common grackles ( $Q$. quiscula) and anthraquinone-treated confectionery sunflower. The capture, care and use of all birds associated with our repellent efficacy studies were approved by the Animal Care and Use Committee of the United States Department of Agriculture's (USDA) National Wildlife Research Center (NWRC Study Protocols QA-1590, QA-1689, QA-1703; S.J. Werner - Study Director).

\section{Seed germination experiments}

We conducted seed germination experiments in August-December 2009 at the NWRC in Fort Collins, Colorado (USA). Our purpose was to evaluate potential effects of anthraquinone seed treatments for germination of seeds associated with avian depredation and our laboratory efficacy studies.

\subsection{Materials and methods}

We conducted three experiments to determine the effects of Avipel ${ }^{\circledR}$ repellent (a.i. 50\% 9,10-anthraquinone; Arkion Life Sciences, New Castle, DE, USA) on germination of confectionery sunflower, oilseed sunflower, and canola seeds. Each experiment had four treatments. We used unadulterated confectionery sunflower (Kaylor of Colorado, Greeley, CO, USA), oilseed sunflower (RanchWay Feed Mills, Fort Collins, CO, USA), and canola seeds (Monsanto Company, St. Louis, MO, USA) as untreated controls. The three remaining treatments included $0 \%, 1 \%$, and $2 \%$ (targeted concentration, wt/wt) anthraquinone seed treatments on confectionery sunflower (Seeds 2000, Breckenridge, MN, USA), oilseed sunflower (Seeds 2000), and canola (Monsanto Company). Commercial sunflower seeds provided by Seeds 2000 included Apron XL ${ }^{\circledR}$ LS/Maxim ${ }^{\circledR} 4$ FS seed treatment fungicides (Syngenta Crop Protection, Greensboro, NC, USA) and Cruiser ${ }^{\circledR} 5$ FS seed treatment insecticide (Syngenta Crop Protection). Commercial canola seeds provided by Monsanto Company included Helix $\mathrm{XTra}{ }^{\circledR}$ seed treatment insecticide and fungicide (Syngenta Crop Protection).

We formulated seed treatments for our germination experiments by applying aqueous solutions $(60 \mathrm{~mL}$ solution/ $\mathrm{kg}$ seed) to confectionery sunflower, oilseed sunflower, and canola seeds using a rotating mixer and household spray equipment. For each treatment, we placed 10 seeds in each of 20 petri dishes $(9.5 \mathrm{~cm}$ diameter) lined with a hydrated (3.5 mL de-ionized water) kimwipe ${ }^{\circledR}$ (Kimberly-Clark Global Sales, Inc., Roswell, GA, USA). We subsequently sealed all dishes with parafilm and placed them in an environmental chamber $\left(25 \pm 0.8^{\circ} \mathrm{C}\right.$; Conviron E72 Plant Growth Chamber, Winnipeg, MB, Canada).

We monitored seed germination each $24 \mathrm{~h}$ until $65 \%$ of untreated control seeds had sprouts $\geq 20 \mathrm{~mm}$ (U.S. Environmental Protection Agency [USEPA], 1996). We tallied sprouts $\geq 5 \mathrm{~mm}$ in each dish at the conclusion of each experiment (USEPA, 1996). We calculated 95\% confidence intervals about mean germination for each crop seed (SAS v9.1) and used descriptive statistics to summarize percent germination among our anthraquinone seed treatments for sunflower and canola.

We collected a $200 \mathrm{~g}$ sample of each seed treatment upon formulation for anthraquinone analytical chemistry. We used reversed-phase, high performance liquid chromatography (HPLC; Werner et al., 2009) with ultraviolet detection to quantify anthraquinone concentrations among our experimental seed treatments $( \pm 1 \mathrm{ppm}$ anthraquinone). All samples of our seed treatments were labeled and shipped to Arkion Life Sciences for subsequent analytical chemistry. Samples were received by Arkion Life 


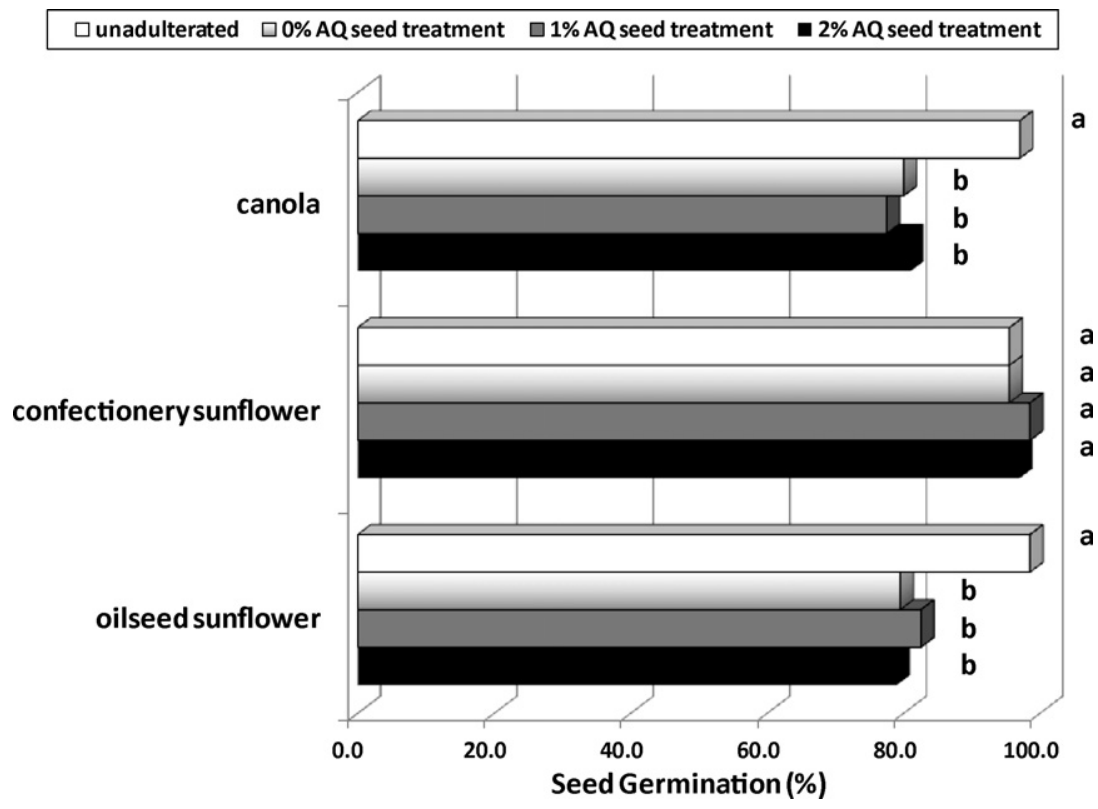

Fig. 1. Mean germination of untreated seeds, and seeds treated with fungicide, insecticide and $0 \%, 1 \%$, or $2 \%$ anthraquinone (AQ) within environmental chambers. Unique letters indicate non-overlapping confidence intervals $(\alpha=0.05)$.

Sciences within $24 \mathrm{~h}$ of formulation, logged in, and immediately transferred to a $4{ }^{\circ} \mathrm{C}$ refrigerator where they were stored for the duration of the analysis period.

\subsection{Results}

Although we observed a difference in germination of canola seeds among our seed treatments, this difference was exclusively attributed to greater germination of unadulterated canola seeds (95\% CI: 95-99\% germination) compared to that of all Monsanto seed treatments (i.e., insecticide and fungicide seed treatments with and without anthraquinone; Fig. 1). Compared to the germination of Monsanto seed treatments not treated with anthraquinone (95\% CI: $74-86 \%$ germination), we observed no negative effects of $5709 \mathrm{ppm}$ anthraquinone (95\% Cl: $72-83 \%)$ and 11,569 ppm anthraquinone (95\% CI: $74-88 \%$ ) for germination of canola seeds (Fig. 1).

Germination of confectionery sunflower seeds was unaffected by our seed treatments. We observed $96-99 \%$ germination among Seeds 2000 seed treatments (i.e., fungicide and insecticide seed treatments with and without anthraquinone; Fig. 1). Anthraquinone concentrations for our $1 \%$ and $2 \%$ anthraquinone treatments (target concentrations) were $5186 \mathrm{ppm}$ anthraquinone and $12,223 \mathrm{ppm}$ anthraquinone, respectively. Thus, we observed no negative effects of up to $12,223 \mathrm{ppm}$ anthraquinone for germination of confectionery sunflower seeds.

Although we observed a difference in germination of oilseed sunflower seeds among our seed treatments, this difference was exclusively attributed to greater germination of unadulterated oilseed sunflower seeds (95\% CI: $97-100 \%$ germination) compared to that of all Seeds 2000 seed treatments (i.e., fungicide and insecticide seed treatments with and without anthraquinone;
Fig. 1). Compared to the germination of Seeds 2000 seed treatments not treated with anthraquinone $(95 \% \mathrm{CI}$ : $75-84 \%$ germination), we observed no negative effects of $5829 \mathrm{ppm}$ anthraquinone (95\% CI: 77-88) and 14,104 ppm anthraquinone (95\% CI: 72-86) for germination of oilseed sunflower seeds (Fig. 1).

\subsection{Discussion}

Compared to the germination of seeds not treated with anthraquinone, we observed no negative effects of up to $12,223 \mathrm{ppm}, 14,104 \mathrm{ppm}$, and $11,569 \mathrm{ppm}$ anthraquinone seed treatments for germination of confectionery sunflower, oilseed sunflower, and canola seeds, respectively. We previously learned that active ingredients associated with Helix XTra ${ }^{\circledR}$ seed treatments used for our canola germination experiment and Apron $\mathrm{XL}^{\circledR} \mathrm{LS} /$ Maxim $^{\circledR} 4$ FS seed treatments used for our sunflower germination experiments were ineffective avian repellents (Werner et al., 2008b). Additional studies are needed to evaluate field residues and potential toxicological impacts associated with anthraquinone repellent applications for development of tolerance concentrations for food and feed use (e.g., confectionery sunflower).

\section{Seed treatment efficacy study with ring-necked pheasants}

We conducted a repellent efficacy study in September 2009 with ring-necked pheasants offered emergent seedlings from anthraquinone-treated sunflower seeds at the NWRC outdoor animal research facility. We used Avipel $^{\circledR}$ repellent for our seed treatment efficacy study. Seedlings were grown within an indoor, simulated natural environment research facility at NWRC. 


\subsection{Materials and methods}

We offered 28 captive-raised ring-necked pheasants emergent sunflower seedlings from $0 \%$ and $2 \%$ (targeted concentration, wt/wt) anthraquinone seed treatments during a caged preference test. Pheasants were maintained in group cages (four pheasants in each of seven, $7.4 \mathrm{~m} \times 3.7 \mathrm{~m} \times 3.1 \mathrm{~m}$ cages) throughout the repellent efficacy study (quarantine, acclimation, testing). We offered the maintenance diet ad libitum (three parts whole corn: one game bird feed; Purina Mills, St. Louis, MO, USA) in each of two food bowls (north and south sides of each cage) throughout a 3-day acclimation period.

We used oilseed sunflower seeds (Seeds 2000) that included Apron $\mathrm{XL}^{\circledR} \mathrm{LS} /$ Maxim ${ }^{\circledR} 4 \mathrm{FS}$ seed treatment fungicides and Cruiser $^{\circledR} 5$ FS seed treatment insecticide for our $0 \%$ and $2 \%$ repellent seed treatments. We formulated seed treatments for our pheasant study by applying aqueous solutions ( $60 \mathrm{~mL}$ solution/ $\mathrm{kg}$ seed) to oilseed sunflower using a rotating mixer and household spray equipment. Sunflower seeds were planted within stainless steel trays $(91 \mathrm{~cm} \times 112 \mathrm{~cm} \times 4 \mathrm{~cm}$; seven trays per treatment) that contained $3 \mathrm{~cm}$ of potting soil. We monitored and maintained growing conditions daily (temperature, light, humidity). We collected a $200 \mathrm{~g}$ sample of each seed treatment upon formulation for anthraquinone analytical chemistry.

On the day subsequent to the acclimation period, we provided each of seven pheasant cages with one tray that contained untreated sunflower seedlings (i.e., south side of cage, randomly selected), and one tray that contained repellent-treated sunflower seedlings (north side of cage), at $09: 30 \mathrm{~h}$ on Wednesday (12 days post-planting). We concluded the study at $10: 30 \mathrm{~h}$, when $>80 \%$ of untreated seedlings were consumed or damaged in three of seven cages. We quantified all undamaged sunflower seedlings prior to the study and all damaged seedling subsequent to the study. Upon inspection of histograms for normality, we used a paired $t$-test (SAS v9.1) and descriptive statistics to analyze percent damage to sunflower seedlings.

\subsection{Results}

We observed less damage to emergent seedlings from our anthraquinone seed treatments (12\% damage; range $=0-43 \%$ ) than untreated seedlings (54\% damage; range $=8-100 \%$ ) during our caged-pheasant preference test $\left(t_{6}=2.52, P=0.045\right)$. We observed $15,800 \mathrm{ppm}$ anthraquinone among our oilseed sunflower seed treatments associated with this study. Thus, pheasants were repelled from emergent seedlings associated with our $2 \%$ anthraquinone seed treatments (targeted concentration), 12 days post-planting.

\subsection{Discussion}

Results from our seed treatment efficacy study suggest that an anthraquinone seed treatment (2\% target concentration) can effectively protect sunflower seedlings from damage caused by ring-necked pheasants. The actual concentration of anthraquinone associated with our oilseed sunflower seed treatments was greater than the reported threshold concentration of anthraquinone for ring-necked pheasants offered treated corn seeds (i.e., 10,450 ppm anthraquinone; Werner et al., 2009). Supplemental field studies of anthraquinone seed treatments are needed to reconcile predicted threshold concentrations developed in captivity with field residues and field efficacy for protection of newly planted sunflower from ring-necked pheasants.

Similar to blackbird damage to newly planted rice (Cummings et al., in press), we observed pheasants removing emergent seedlings from our study trays (i.e., including the treated seed). Conversely, damage to newly planted crops caused by grazing of above-ground phytomass (e.g., Canada goose consumption of newly planted grasses and legumes; Werner et al., unpublished data) is best managed with foliar repellent applications to emergent seedlings.

\section{Laboratory efficacy experiments with common grackles}

We conducted one preference and one concentration-response (i.e., laboratory efficacy) experiment in October-November 2009 to evaluate common grackle consumption of anthraquinone-treated confectionery sunflower seeds (Kaylor of Colorado) at the NWRC outdoor animal research facility. We used Avipel ${ }^{\circledR}$ repellent for our laboratory efficacy experiments.

\subsection{Materials and methods}

We maintained 88 common grackles in $3.1 \mathrm{~m} \times 6.2 \mathrm{~m} \times 3.1 \mathrm{~m}$ cages (20-40 birds/cage) within a wire mesh-sided building at the NWRC outdoor animal research facility for $\geq 2$ weeks prior to our laboratory efficacy experiments (i.e., quarantine, holding). We provided free access to a maintenance diet for all grackles during quarantine and holding, and water ad libitum throughout our laboratory efficacy experiments. The maintenance diet for grackles included two parts millet: one cracked corn: one milo: one safflower.

Laboratory efficacy experiments were conducted in individual cages $(0.9 \mathrm{~m} \times 1.8 \mathrm{~m} \times 0.9 \mathrm{~m})$ within a wire mesh-sided building. We formulated seed treatments for our experiments by applying aqueous solutions $(60 \mathrm{~mL}$ solution/ $\mathrm{kg}$ seed) to confectionery sunflower using a rotating mixer and household spray equipment. Daily seed consumption was measured throughout the experiments (study days 1-4). Unconsumed seeds (remaining in food bowls) and spillage were collected (at 08:00-09:30 h, daily) and weighed $( \pm 0.1 \mathrm{~g})$. Consumption was measured independently for the north and south food bowls offered during the preference experiment. Weight change (e.g., desiccation) of seeds was measured daily by weighing seeds offered within a vacant cage throughout our experiments.

\subsubsection{Preference experiment}

We randomly assigned 11 common grackles to our sunflower preference (i.e., choice) experiment. We offered all grackles untreated confectionery sunflower seed ad libitum in two food bowls for 5 days of acclimation in individual 
cages. We subsequently offered each grackle one bowl of untreated sunflower and one bowl of sunflower treated with $0.25 \%$ anthraquinone (targeted concentration, wt/wt) at 08:00-09:30 h, daily. The north-south placement of food bowls was randomized on the first day and alternated on subsequent days of the preference experiment.

The dependent measure for our preference experiment was average (i.e., daily) test consumption of treated and untreated seeds. After successfully conducting Levene's test for equal variances ( $\alpha=0.05$ ), consumption data for the preference experiment were subjected to a repeated measures ANOVA (SAS v9.1). The random effect of our model was bird subjects, the between-subjects effect was treatment (treated vs. untreated seed), and the within-subject effect was test day. We analyzed the treatment effect and the treatment by day interaction using a mixed model (SAS v9.1). We used Tukey's tests to separate means of ANOVA interactions ( $\alpha=0.05)$. We used descriptive statistics $(\bar{x} \pm$ S.E.M.) to summarize consumption of treated and untreated seeds during the preference experiment.

\subsubsection{Concentration-response experiment}

We conducted a no-choice experiment to establish a concentration-response relationship of anthraquinonetreated sunflower for common grackles. We offered 77 common grackles untreated confectionery sunflower seed ad libitum in one food bowl for 5 days of acclimation in individual cages. We subsequently offered each grackle $30 \mathrm{~g}$ of untreated sunflower seeds in one bowl during each of study days 1-3. We ranked grackles based upon average pretreatment consumption and assigned them to one of eight treatment groups ( $n=9-11$ grackles/group) such that each group was similarly populated with birds that exhibited high-low daily consumption. We randomly assigned treatments among groups $(0.02 \%, 0.035 \%, 0.05 \%$, $0.1 \%, 0.25 \%, 0.5 \%, 1 \%$, and $2 \%$ anthraquinone; targeted concentrations, wt/wt). We offered $30 \mathrm{~g}$ of treated sunflower seeds in one bowl to all birds on study day 4 , and determined the mass $( \pm 0.1 \mathrm{~g})$ of uneaten seeds and seed spillage at 08:00-09:30 h on study day 5 . We collected a $200 \mathrm{~g}$ sample of each seed treatment upon formulation for anthraquinone analytical chemistry.

We hypothesized that repellency would be directly related to repellent concentration during our concentration-response experiment. We previously established $\geq 80 \%$ repellency as efficacious during our laboratory feeding experiments (Werner et al., 2007, 2008a,b, 2009, 2010). Thus, we predicted that consumption of efficacious treatments (i.e., threshold repellency) would be $<20 \%$ of pretreatment consumption during the grackle concentration-response experiment. The dependent measure of our concentration-response experiment was calculated as test consumption of treated seeds relative to average pretreatment consumption of untreated seeds (i.e., percent repellency). We used non-linear regression procedures (SAS v9.1) to analyze repellency as a function of anthraquinone concentration (ppm). We used descriptive statistics $(\bar{x} \pm$ S.E.M.) to summarize consumption ( $\mathrm{mg}$ anthraquinone $/ \mathrm{kg}$ body mass [BM]) of treated seeds during our concentration-response experiment.

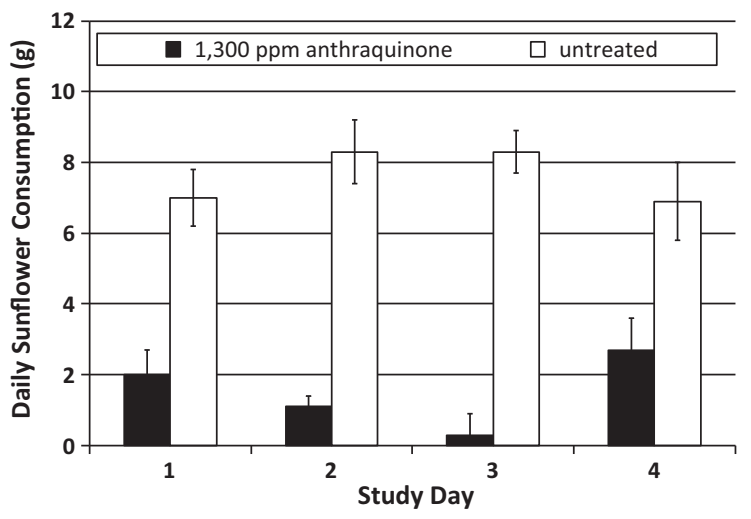

Fig. 2. Mean consumption ( \pm S.E.M.) of confectionery sunflower seeds offered to common grackles (Quiscalus quiscula). Grackles were offered untreated seeds and seeds treated with Avipel ${ }^{\circledR}$ repellent (a.i. 50\% 9,10anthraquinone).

\subsection{Results}

Common grackles reliably discriminated between untreated confectionery sunflower seeds and those treated with $1300 \mathrm{ppm}$ anthraquinone during the preference experiment $\left(F_{1,10}=119.60, P<0.001\right)$. Grackles consumed an average of $1.5 \pm 0.3 \mathrm{~g}$ of treated sunflower and $7.6 \pm 0.4 \mathrm{~g}$ of untreated sunflower during the 4-day experiment (Fig. 2). We observed no treatment by day interaction during the sunflower preference experiment $\left(F_{6,60}=1.37\right.$, $P=0.2433$ ).

We observed a positive concentration-response relationship among tested concentrations of anthraquinone on confectionery sunflower seeds (Fig. 3). Common grackles exhibited $>80 \%$ repellency for sunflower treated with $12,220 \mathrm{ppm}$ anthraquinone (Fig. 3), or $194.4 \pm 39.1 \mathrm{mg}$ anthraquinone $/ \mathrm{kg}$ BM. Grackle repellency $(y)$ was a function of anthraquinone concentration $(x)$ : $y=23.54 \ln (x)-134.87 \quad\left(r^{2}=0.85, P=0.001\right)$. We therefore predicted a threshold concentration of $9200 \mathrm{ppm}$

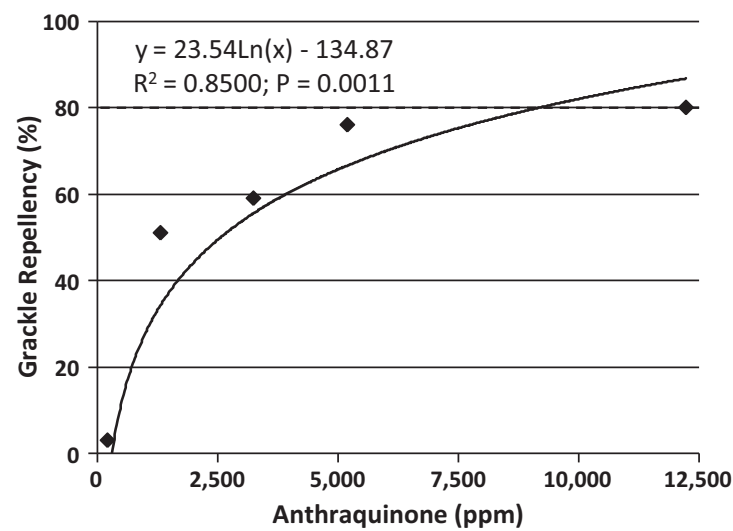

Fig. 3. Mean feeding repellency associated with varying concentrations of Avipel $^{\circledR}$ seed treatments (a.i. 50\% 9,10-anthraquinone) offered to common grackles (Quiscalus quiscula). Repellency represents test consumption relative to average, pretreatment consumption of confectionery sunflower ( $n=8-11$ grackles/concentration). 
anthraquinone (i.e., $80 \%$ repellency) for common grackles offered treated confectionery sunflower seeds.

\subsection{Discussion}

Based upon our laboratory efficacy results, we predicted a threshold concentration of $9200 \mathrm{ppm}$ anthraquinone for common grackles (90-140 g BM). Comparable threshold concentrations for Canada geese $(4300-4900 \mathrm{~g} \mathrm{BM})$ and red-winged blackbirds (45-75 g BM) were $1450 \mathrm{ppm}$ and $1475 \mathrm{ppm}$ anthraquinone, respectively; thus, efficacy of anthraquinone-based repellents is not merely related to subject body mass (Werner et al., 2009). Supplemental experiments are needed to elucidate sufficient modes of action of effective avian repellents. Moreover, supplemental field studies of anthraquinone-based repellents are needed to reconcile predicted threshold concentrations developed in captivity with pre- and at-harvest field residues for protection of ripening (e.g., oilseed) sunflower from blackbird depredation.

\section{Field efficacy study with common grackles}

We conducted a field efficacy study in September-October 2009 to evaluate anthraquinone as an avian repellent within a ripening confectionery sunflower field at Colorado State University's Agricultural Research, Development and Education Center in Fort Collins, Colorado. We used Avipel ${ }^{\circledR}$ repellent for our field efficacy study.

\subsection{Materials and methods}

The confectionery sunflower field was planted on June 30, 2009. We established 20 enclosures, or netted plots (each $3.7 \mathrm{~m} \times 4.0 \mathrm{~m} \times 1.8-3.1 \mathrm{~m}$ ) within the maturing sunflower field on July $14-15$. For ripening sunflower, $>75 \%$ of annual blackbird damage occurs within the first 18 days after anthesis (Cummings et al., 1989). The end of anthesis (i.e., flowering period) for sunflower is marked by the emergence of the last anther, which coincides with the beginning of yellow ray flower drop (Siddiqui, 1975). Thus, we applied Avipel ${ }^{\circledR}$ repellent on September 14, when $>50 \%$ of sunflower within our enclosures was at the R- 6 growth stage (i.e., anthesis complete, ray flowers wilting or falling).

We conducted preliminary laboratory residue testing with confectionery sunflower heads treated with Avipel ${ }^{\circledR}$ applications comparable to $9.4 \mathrm{~L}$ per ha, $18.7 \mathrm{~L}$ per ha, and $37.4 \mathrm{~L}$ per ha; we observed $3489 \mathrm{ppm}, 6001 \mathrm{ppm}$, and $16,638 \mathrm{ppm}$ anthraquinone among seeds sampled from these treated sunflower heads, respectively. Based upon our predicted threshold concentrations for anthraquinone repellency (Werner et al., 2009), we used a backpack $\mathrm{CO}_{2}$ sprayer to apply $18.7 \mathrm{~L} \mathrm{Avipel}^{\circledR}$ repellent per ha to all sunflower heads within our treated field enclosures.

We collected a $100 \mathrm{~mL}$ sample of each repellent tank formulation and all liquid samples were frozen in a labeled amber jar for anthraquinone analytical chemistry. We used ultraviolet/visible (UV/VIS) spectrophotometry to analyze anthraquinone concentrations ( $\pm 1 \mathrm{ppm}$ anthraquinone) among tank mixtures associated with our field efficacy study. All samples of our repellent tank mixtures were labeled and shipped to Arkion Life Sciences for subsequent analytical chemistry. Samples were again received by Arkion Life Sciences within $24 \mathrm{~h}$ of formulation, logged in, and immediately transferred to a $4{ }^{\circ} \mathrm{C}$ refrigerator where they were stored for the duration of the analysis period. We redispersed and diluted all field samples with tetrahydrofuran. Replicate aliquots from each sample were prepared and analyzed. Sample bottles were shaken and placed in an ultrasonic bath to redisperse precipitate. A small aliquot of each sample was transferred to a preweighed vial and reweighed. Samples were diluted with $15 \mathrm{~mL}$ of tetrahydrofuran, sealed and sonicated for $30 \mathrm{~min}$. Each sample vial was cooled and reweighed to account for any solvent loss in the sample. Each sample response was measured at $323 \mathrm{~nm}$, with tetrahydrofuran as reference. Quartz photometric cells with a path length of $10 \mathrm{~mm}$ were used to quantify anthraquinone concentration.

On the day subsequent to the repellent application (September 15), we populated each of the 20 enclosures with 10 grackles. We maintained 10 grackles per enclosure throughout the study. Grackles fed freely within field enclosures throughout the 15-day study. We provided a maintenance diet (milo) ad libitum in all treated and untreated enclosures throughout the field study. We measured consumption of the maintenance diet $( \pm 1 \mathrm{~g})$ on alternate days throughout the study (beginning day 3 ). We removed grackles from all enclosures on test day 15 when we observed $\geq 70 \%$ sunflower damage within five of 10 untreated enclosures (September 30).

We evaluated repellent efficacy based upon comparative sunflower damage and harvested seed mass (i.e., sunflower yield) between repellent-treated and untreated enclosures. We manually harvested all sunflower heads within treated and untreated enclosures on October 2. Upon manual harvest, we visually estimated damage (i.e., seed removal; $\pm 10 \%$ surface area) of each head in all enclosures using graduated-transparency templates $(10 \mathrm{~cm}, 15 \mathrm{~cm}, 20 \mathrm{~cm}, 25 \mathrm{~cm}$, and $30 \mathrm{~cm}$ diameter). We used a stationary thresher (USDA Agricultural Research Service, Akron, CO, USA) to remove sunflower seeds from harvested heads. We dried and weighed all harvested seeds to determine sunflower yield for each enclosure $( \pm 1.00 \mathrm{~kg})$. All treated sunflower was destroyed upon the completion of the study per existing pesticide regulations.

After successfully conducting Levene's test for equal variances $(\alpha=0.05)$, we used a repeated measures ANOVA to evaluate maintenance diet consumption within treated and untreated enclosures throughout our field efficacy study. The random effect of our models was enclosures, the between-subjects effect was treatment (treated vs. untreated enclosures), and the within-subject effect was test day. We analyzed the treatment effect and the treatment by day interaction using a mixed model (SAS v9.1). We used Tukey's tests to separate means of ANOVA interactions $(\alpha=0.05)$. We used descriptive statistics $(\bar{x} \pm$ S.E.M. $)$ to summarize maintenance diet consumption within treated and untreated enclosures.

Upon inspection of histograms for normality, we used a paired $t$-test to analyze percent damage to sunflower heads and comparative sunflower yield associated with our 


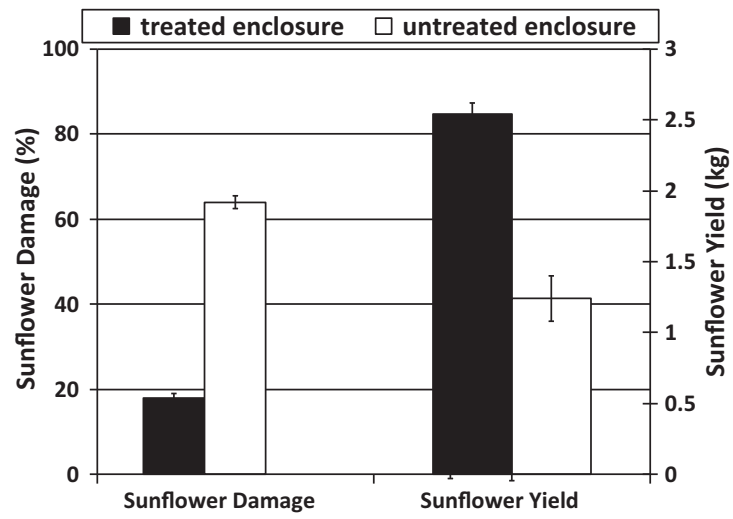

Fig. 4. Mean sunflower damage and sunflower yield ( \pm S.E.M.) among repellent-treated and untreated enclosures in a ripening confectionery sunflower field. Common grackles (Quiscalus quiscula) were maintained in experimental enclosures ( $n=10$ enclosures per treatment, 10 grackles/enclosure) for 15 days subsequent to the repellent application. Avipel ${ }^{\circledR}$ repellent ( $18.7 \mathrm{~L}$ per ha; a.i. $50 \%$ 9,10-anthraquinone) was applied to all sunflower heads within treated enclosures using a $\mathrm{CO}_{2}$ backpack sprayer at the R-6 growth stage (anthesis complete, ray flowers wilting/falling).

field efficacy study (SAS v9.1). We used descriptive statistics to summarize sunflower damage and yield between repellent-treated and untreated enclosures.

\subsection{Results}

Upon our field application, the concentration of anthraquinone within tank mixtures was $10.7 \%$ $(106,700 \mathrm{ppm})$ anthraquinone (wt/wt). Common grackles consumed more maintenance diet within enclosures treated with anthraquinone than within untreated enclosures throughout the 15-day field study $\left(F_{1,9}=41.05\right.$, $P<0.001)$. Grackles consumed an average of $200.6 \pm 5.4 \mathrm{~g}$ of milo per day within treated enclosures and $176.8 \pm 4.5 \mathrm{~g}$ of milo per day within untreated enclosures. We also observed a treatment by day interaction during the field efficacy study $\left(F_{12,108}=30.37, P<0.001\right)$; milo consumption was greater within treated enclosures on day 13 post-application of the anthraquinone-based repellent (Tukey $P=0.033$ ).

We observed $18 \%$ damage among anthraquinonetreated enclosures and 64\% damage among untreated enclosures populated with common grackles $\left(t_{9}=9.63\right.$, $P<0.001$; Fig. 4). Harvested seed mass averaged $2.54 \mathrm{~kg}$ (dry weight) among treated enclosures and $1.24 \mathrm{~kg}$ among untreated enclosures $\left(t_{9}=6.48, P<0.001\right.$; Fig. 4). Thus, our foliar application of an anthraquinone-based repellent on ripening confectionery sunflower affected greater consumption of the alternative maintenance diet (milo), less sunflower damage, and greater sunflower yield within treated enclosures.

\subsection{Discussion}

Compared to our untreated field enclosures, we observed less damage and greater yield among sunflowers treated with $18.7 \mathrm{~L}$ Avipel ${ }^{\circledR}$ per ha. This anthraquinonebased repellent therefore effectively protected ripening confectionery sunflower from damage caused by common grackles. Compared to our predicted threshold concentration of $9200 \mathrm{ppm}$ anthraquinone for common grackles offered confectionery sunflower seeds, the reported threshold concentration of anthraquinone for red-winged blackbirds offered treated oilseed sunflower was 1475 ppm anthraquinone (Werner et al., 2009). We therefore recommend a replicate field efficacy study with red-winged blackbirds and ripening oilseed sunflower treated with 4.5-9 L Avipel ${ }^{\circledR}$ per ha.

Whereas our field application was made using a $\mathrm{CO}_{2}$ backpack sprayer within small enclosures $(3.7 \mathrm{~m} \times 4.0 \mathrm{~m})$, development of commercial application strategies is presently needed for chemical repellents and management of agricultural depredation. Although we recommend supplemental field efficacy testing of anthraquinone-based and other chemical repellents using larger plots, pesticide regulations limit agricultural applications of unregistered products to 4 ha annually in the USA.

Bird damage problems in Latin America are similar to those in the USA, involving many of the same types of crops and genera of birds (De Grazio and Besser, 1970). For example, eared doves (Zenaida auriculata) are the greatest pest economically for sunflower production in Uruguay (Rodriguez, 1994). Eared doves are considered both national and provincial pests in Argentina primarily because of their damage to sunflower, wheat, and sorghum (Bruggers and Zaccagnini, 1994). Anthraquinone-based repellents are already registered for several agricultural crops in Uruguay (Rodriguez et al., 2004). We recommend supplemental field studies of anthraquinone-based repellents for protection of ripening sunflower using an expanded spatial scale and commercial application procedures (e.g., self-propelled, ground-based sprayers). Such studies are planned for the 2011 growing season in the USA and South America.

\section{Conclusion}

Avipel $^{\circledR}$ seed treatments (a.i. 9,10-anthraquinone) effectively repelled ring-necked pheasants and common grackles in captivity. Compared to observed damage within untreated field enclosures, common grackles damaged fewer ripening confectionery sunflowers treated with a foliar application of Avipel ${ }^{\circledR}$ repellent via a $\mathrm{CO}_{2}$ backpack sprayer. Our laboratory and field efficacy data provide a reliable basis for planning future field applications of anthraquinone-based repellents for protection of sunflower crops. Supplemental field efficacy studies are necessary for development of an effective avian repellent and management of avian depredation of newly seeded and ripening agricultural crops. Future repellent efficacy studies should include: (1) application strategies that are specifically developed to protect agricultural crops from avian depredation; (2) independent field replicates with predicted bird damage; (3) varied application rates based upon species-specific threshold concentrations, including untreated controls; (4) pre- and at-harvest analytical chemistry; (5) bird damage measurements; and (6) crop yield measurements. 


\section{Acknowledgements}

This research was supported by the National Sunflower Association (Mandan, ND, USA). Our field efficacy study was partially funded by the North Dakota Oilseed Council (Mandan, ND, USA). Our germination and feeding experiments were conducted with Avipe ${ }^{\circledR}$ repellent (Arkion ${ }^{\circledR}$ Life Sciences, New Castle, DE, USA). Corporate collaborations do not imply endorsement by the United States Department of Agriculture. We appreciate the National Wildlife Research Center animal care staff that provided daily care of all birds throughout quarantine and holding for our repellent efficacy studies. We thank M. Klosterman, A. Slowik, and M. Strassburg for their dedicated assistance as we established our 2009 sunflower field enclosures. We also thank S.B. Canavelli, D.A. Goldade, B.A. Kimball, L.A. Orduna, E.N. Rodriguez, and M.E. Tobin for constructive feedback from their review of our manuscript.

\section{References}

Avery, M.L., Humphrey, J.S., Decker, D.G., 1997. Feeding deterrence of anthraquinone, anthracene, and anthrone to rice-eating birds. J. Wildl. Manage. 61, 1359-1365.

Avery, M.L., Humphrey, J.S., Primus, T.M., Decker, D.G., McGrane, A.P., 1998. Anthraquinone protects rice seed from birds. Crop Prot. 17, 225-230.

Avery, M.L., Werner, S.J., Cummings, J.L., Humphrey, J.S., Milleson, M.P., Carlson, J.C., Primus, T.M., Goodall, M.J., 2005. Caffeine for reducing bird damage to newly seeded rice. Crop Prot. 24, 651-657.

Bruggers, R.L., Zaccagnini, M.E., 1994. Vertebrate pest problems related to agricultural production and applied research in Argentina. Vida Sylv. Neotrop. 3, 71-83.

Cummings, J.L., Avery, M.L., Mathre, O., Wilson, E.A., York, D.L., Engeman, R.M., Pochop, P.A., Davis Jr., J.E., 2002a. Field evaluation of Flight Control ${ }^{\mathrm{TM}}$ to reduce blackbird damage to newly planted rice. Wildl. Soc. Bull. 30, 816-820.

Cummings, J.L., Byrd, R.W., Eddleman, W.R., Engeman, R.M., Tupper, S.K. Effectiveness of AV-1011 ${ }^{\circledR}$ to reduce damage to drill-planted rice from blackbirds. J. Wildl. Manage., in press.

Cummings, J.L., Guarino, J.L., Knittle, C.E., 1989. Chronology of blackbird damage to sunflowers. Wildl. Soc. Bull. 17, 50-52.

Cummings, J.L., Pochop, P.A., Engeman, R.M., Davis Jr., J.E., Primus, T.M., 2002b. Evaluation of Flight Control ${ }^{\circledR}$ to reduce blackbird damage to newly planted rice in Louisiana. Int. Biodeterior. Biodegr. 49, 169-173.
De Grazio, J.W., Besser, J.F., 1970. Bird damage problems in Latin America. Vert. Pest Conf. 4, 162-167.

Heckmanns, F., Meisenheimer, M., 1944. Protection of seeds against birds. Patent 2,339,335. U.S. Patent Office, Washington, D.C.

Linz, G.M., Hanzel, J.J., 1997. Birds and sunflower. Sunflower Technology and Production. Agron. Monogr. 35, 881-894.

Linz, G.M., Homan, H.J., Slowik, A.A., Penry, L.B., 2006. Evaluation of registered pesticides as repellents for reducing blackbird (Icteridae) damage to sunflower. Crop Prot. 25, 842-847.

Merck, 1991. In: Fraser, C.M., Bergeron, J.A. (Eds.), Merck Veterinary Manual, 7th ed. Merck \& Co., Inc., USA, p. 1383.

Neff, J.A., Meanley, B., 1957. Research on Bird Repellents: Bird Repellent Studies in the Eastern Arkansas Rice Fields. Wildlife Research Laboratory, Denver, CO, $21 \mathrm{pp}$.

Peer, B.D., Homan, H.J., Linz, G.M., Bleier, W.J., 2003. Impact of blackbird damage to sunflower: bioenergetic and economic models. Ecol. Appl. $13,248-256$.

Rodriguez, E., 1994. An integrated strategy to decrease eared dove damage in sunflowers. Ph.D. Dissertation. Colorado State University.

Rodriguez, E.N., Tiscornia, G., Tobin, M.E., 2004. Bird depredations in Uruguayan vineyards. Vert. Pest Conf. 21, 136139.

Siddiqui, M.Q., 1975. Growth stages of sunflowers and intensity indices for white blister and rust. Plant Dis. Rep. 59, 7-11.

USEPA, 1996. Ecological Effects Test Guidelines. Seed Germination/Root Elongation Toxicity Test. U.S. Environmental Protection Agency (USEPA), Washington, DC, USA, EPA 712-C-96154.

Werner, S.J., Carlson, J.C., Tupper, S.K., Santer, M.M., Linz, G.M., 2009. Threshold concentrations of an anthraquinone-based repellent for Canada geese, red-winged blackbirds, and ring-necked pheasants. Appl. Anim. Behav. Sci. 121, 190-196.

Werner, S.J., Cummings, J.L., Pipas, P.A., Tupper, S.K., Byrd, R.W., 2008a. Registered pesticides and citrus terpenes as blackbird repellents for rice. J. Wildl. Manage. 72, 1863-1868.

Werner, S.J., Cummings, J.L., Tupper, S.K., Goldade, D.A., Beighley, D., 2008b. Blackbird repellency of selected registered pesticides. J. Wildl. Manage. 72, 1007-1011.

Werner, S.J., Cummings, J.L., Tupper, S.K., Hurley, J.C., Stahl, R.S., Primus, T.M., 2007. Caffeine formulation for avian repellency.J. Wildl. Manage. $71,1676-1681$.

Werner, S.J., Homan, H.J., Avery, M.L., Linz, G.M., Tillman, E.A., Slowik, A.A., Byrd, R.W., Primus, T.M., Goodall, M.J., 2005. Evaluation of Bird Shield ${ }^{\mathrm{TM}}$ as a blackbird repellent in ripening rice and sunflower fields. Wildl. Soc. Bull. 33, 251-257.

Werner, S.J., Linz, G.M., Tupper, S.K., Carlson, J.C., 2010. Laboratory efficacy of chemical repellents for reducing blackbird damage in rice and sunflower crops. J. Wildl. Manage. 74, 1400-1404.

West, R.R., Brunton, R.B., Cunningham, D.J., 1969. Repelling pheasants from sprouting corn with a carbamate insecticide. J. Wildl. Manage. 71, 216-219. 